Vol. 11 (4): 927-930 (2021)

\title{
EFFECTIVENESS OF GROWING SORGHUM IN THE ALTAI TERRITORY
}

\author{
Sergey Ivanovich Kapustin ${ }^{1,2}$, Alexander Borisovich Volodin ${ }^{1}$, Andrey Sergeevich Kapustin ${ }^{3 *}$, \\ Olga Ivanovna Vlasova ${ }^{2}$, Inna Anatolievna Donets ${ }^{2}$ \\ ${ }^{I}$ North Caucasus Federal Agrarian Research Centre, Nikonov str. 49, Mikhailovsk, \\ Stavropol region, 356241, Russia; \\ ${ }^{2}$ Stavropol State Agrarian University, 12 Zootechnicheskiy Ln, Stavropol, 355017, Russia; \\ ${ }^{3 *}$ North Caucasus Federal University, Pushkin str. 1, Stavropol, 355017, Russia.
}

"Corresponding Author Andrey Sergeevich Kapustin, e-mail: hpplus@bk.ru;

Received August 2021; Accepted September 2021; Published October 2021;

DOI: $\underline{\text { https://doi.org/10.31407/ijees11.433 }}$

\begin{abstract}
Increasing the cultivation area of the most valuable crops, replacing unproductive varieties and hybrids with more productive ones is a significant reserve for strengthening the forage base and improving its quality. Despite the fact that the varieties and hybrids of sorghum of "North Caucasus Federal Agricultural Research Centre" breeding, which were studied in 2019-2020 in the Altai Territory, were inferior to local standards in terms of the duration of the growing season and seed yield, they significantly exceeded them in plant height, yield of green and dry matter, the content of digestible protein in 1 forage unit and metabolic energy. The average two-year rates indicate that the most significant plant height was found in the hybrid of sweet sorghum Yarik $(240.5 \mathrm{~cm})$ and the new sorghumsudangrass hybrid Gvardeets $(247 \mathrm{~cm})$. The highest yield of green and dry matter were obtained from hybrids of sweet sorghum Yarik (43.0 t/ha and $12.8 \mathrm{t} / \mathrm{ha}$, respectively), Silosnoe 88 (43.6 t/ha and $12.4 \mathrm{t} / \mathrm{ha})$, variety Larets (43.4 t/ha and $12.7 \mathrm{t} / \mathrm{ha}$ ), undergoing state variety testing Tandem (42.9 t/ha and $12.0 \mathrm{t} / \mathrm{ha}$ ), as well as the new sorghum-sudangrass hybrid Gvardeets (40.3 t/ha and 11.1 t/ha). The standard Duplet provided $25.7 \mathrm{t} / \mathrm{ha}$ of green and $8.5 \mathrm{t} / \mathrm{ha}$ of dry matter during the experimental years. In comparison with the standard, these hybrids and varieties exceeded in the content of digestible protein in $1 \mathrm{~kg}$ of dry feed by 13-26 g, carotene by 13.9-115.9 g, forage units by $0.01-0.02$.
\end{abstract}

Key words: sweet sorghum, sorghum-sudangrass hybrid, environmental testing, yield, green matter, dry matter. 